\title{
放射線によるブロピレン, プテン-1，およびイソブチレンと一酸化炭素の共重合
}

(昭和 39 年 7 月 30 日受理)

浜ノ上熊男**.田烟 米 穂*・祖父江 寞***

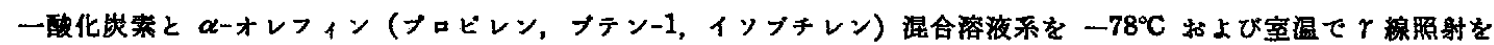
行ない, 共更合物であるボリケトンを得た。

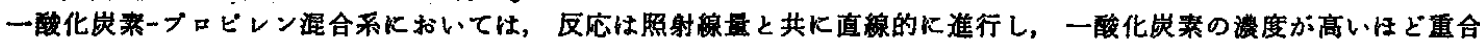
速度は速く，分子量は低い。従って，開始反灾および連鎖移動反応に打いては一酸化岸素が重要な役割を演しているるの

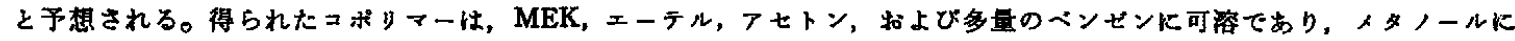

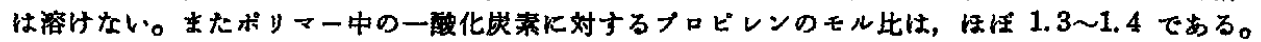

\section{1 楮曹}

一瞈化炭案は有機合成化学における重要な原料であり，たとえ ば二重結合に一酸化炭素を付加させる，いわゆる Oxo process と呼ばれる Reppe 反応は，既にわが国でる工莱化されている。 また, 石油化学工業の発展に伴ない, 有機合成原料としての $\alpha$ オレフィンは，ますます重要な原料になりつつある。

他方, 高分子合成に拈ける一酸化炭素の利用は非常に少なく, 触媒重合飞括いては，エチレン1)，ホルムアルデヒド2) おひひ $\alpha$ -

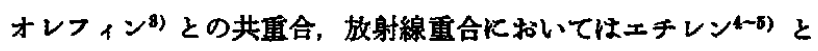
の共重合が知られているのみである。

著者らは，放射線による共重合の研究の立堨から， $\alpha$-オレフィ ン（プロピレン,ブテン 1,イッブチレン）々一酸化炭素の共重合 の可能性について，二三の予潇的榆討を行なったので埌告する。

\section{2 实駧}

\section{$2 \cdot 1$ 陚 料}

プロピレンは新日本空素から提供して戴いた純度 $99.71 \%$ の のをそのまま用いた。ブテン-1, イソブチレンは市販品を trap to trap distillation 法に上り精製した。一酸化炭案恃市肘品をそ のまま使用した。

\section{$2 \cdot 2$ 欲料の仕込}

試料の仕込装圈を图 1 亿示す。反応管（R）はステンレス製ジ ロイント付街圧ガラス反庆管で, 容量 $20 \mathrm{ml}$, 耐压 $100 \mathrm{~kg} / \mathrm{cm}^{2}$ である。

モノマーの仕込に際しては，ます窓素ガス $\left(75 \mathrm{~kg} / \mathrm{cm}^{2}\right)$ にっ て，系の霜圧およびリークテストを行なった。

* Yoneho TABATA 東京大学工学部原子力工学科 : 東京都 交京区本富士町.

** Kumao HAMANOUE 現住所 ; 京都大学理学部化学科 : 京 都市左京区吉田本町.

*** Hiroshi SOBUE 現住所; 成踟大学工学部 : 東京都武藏野 市吉祥寺.

1) M. M. Brubaker, D. D. Coffman, H. H. Hoehn, J. Am. Chem. Soc. 74, 1509 (1952).

2) M. Modena, M. Raggazzini, E. Gallinella, Polymer Letters 1, 567 (1963).

3) W.E. Loeb (Union Carbide Co.), Patent Specification 925, 130 (1963).

4) 渑沢，阪大䜌維研年報，No. 12，72，78 (1959).

5) P. Colombo, M. Steinberg, D. Macchia, Polymer Letters 1. 483 (1963).
プロピレンの仕込は，反底管 $(\mathrm{R})$ をドライアイスーメタノール で冷却し，一定量を液化させた。一酸化崖素は仕力計（P）の目 盛を珫みながら，一定圧のガスを導入した。

ブテン-1，イソブチレンの昜合は，液体空素で椧却した反応管 （R）をモノマー容器に連結し， trap to trap distillation 法によ ク一定量を液化させ,プロピンンの場合と同様にして一酸化筷素 を導入した。

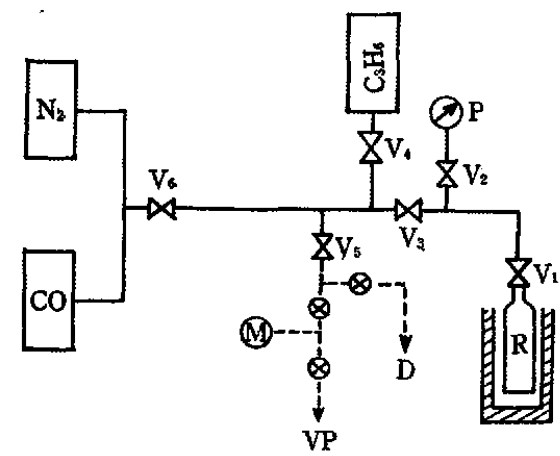

図 1 モノマー仕込装置

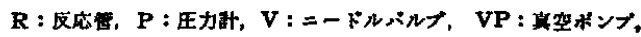

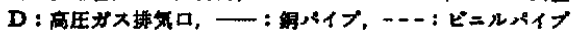

\section{$2 \cdot 3$ 合}

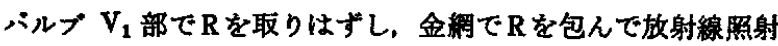

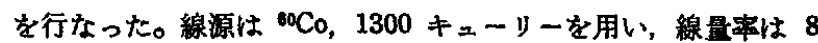
$\times 10^{4} \mathrm{r} / \mathrm{hr}$ である。なお, 重合系は, モノマー(液相)一C $\mathrm{CO}$ (液相) 一CO(気相) から成る系である。

得られたポりマーは，元素分析，赫外吸収スペクトル，粘度測 定によって検討した。な捇外分光光度計は主に Perkin Elmer -21 型を用いた。

\section{3 結果むよび考暴}

\section{1 一酸化炭来 (CO)-ブロビレン (PP) の共重合}

一䜵化炭妻むプロピレンも放射線によっては重合し難いモノ、 一である※2。著者らは，放射線により，これらモノマーが液相て 共重合し得ることを見出した※1。

※1 予骕実験として，気相における共重合を行なったが，嵒射 線量，照射温度が本研究での条件下ではコボリマーを得る 柬は出来なかった。従って, 共重合は液相(liq. PP-dissolved CO) Kおいて行なわれるるのと思われる。

※2ブロピレンは 5000 15000 atm の高压で低分子量のポリい 一が得られる。 


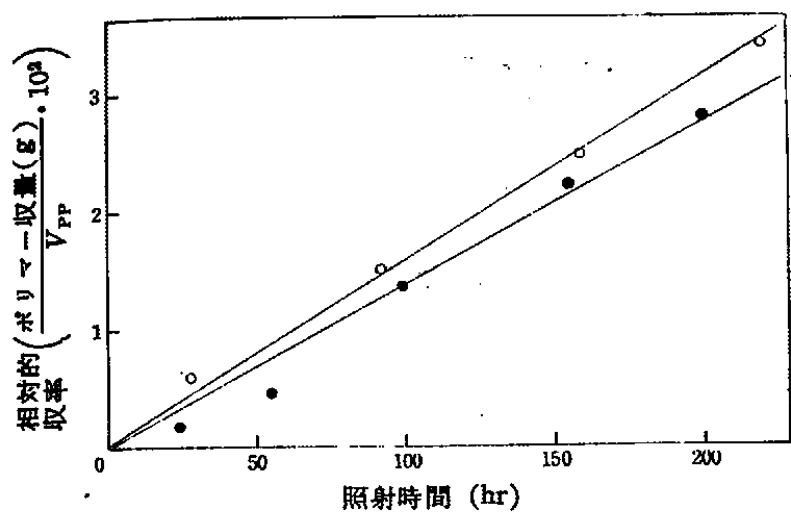

図 2 照射時間と重合率

$\mathrm{O}: P_{\mathrm{co}}=30 \sim 32 \mathrm{~kg} / \mathrm{cm}^{2}$ (at $-78 \mathrm{C}$ )

- : $P_{\mathrm{co}}=20 \sim 22 \mathrm{~kg} / \mathrm{cm}^{2}$ (at $-78 \mathrm{C}$ )

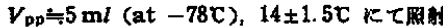

その結夥を図 2 亿示す。重合収率 $(Y)$ は相対的な值として次 武によって求めた。

$$
Y(\%)=\frac{\text { ポリマー重量 }}{\text { PP 体程 }\left(-78^{\circ} \mathrm{C}\right)} \times 100
$$

なお，生力は $-78^{\circ} \mathrm{C}$ に和ける $\mathrm{CO}$ の仕込みゲージ圧を示して おり, $14 \pm 1.5^{\circ} \mathrm{C}$ では $2 \sim 3 \mathrm{~kg} / \mathrm{cm}^{2}$ ほど高くなる。

重合は照射時間（照射線量）と共火直線的に進行しており，誘 萁期恃認められない。定性的ではあるが，王力が高いほど（従っ て, 溶解 CO 量が多い汪ど), 高収率を得ることができる。

種々の条件下に扔ける重合の結果を表 1 に示す。上記の埸合と 同様、压力が简いほど，重合取密は增加しており，低温 $\left(-78^{\circ} \mathrm{C}\right)$ においては著しく減少する。

\section{表 1 共重合に対するCO 王および温度の影签}

\begin{tabular}{|c|c|c|c|c|c|}
\hline 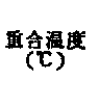 & 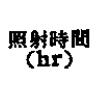 & 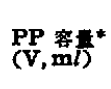 & $\begin{array}{c}\text { CO Ex } \\
\left(\begin{array}{cc}P^{*} \\
\text { kg/cm }\end{array}\right.\end{array}$ & $\underset{\left(\mathbf{k g} / \mathbf{c m}^{\mathbf{a}}\right.}{P_{\mathrm{ml} l)}}$ & 紧事) \\
\hline $14 \pm 1.5$ & 92.4 & 6.0 & 31 & 5.2 & 1.49 \\
\hline$"$ & 99.1 & 5.7 & 20 & 3.5 & 1.35 \\
\hline-78 & 88.7 & 5.5 & 22 & 4.0 & 0.07 \\
\hline $14 \pm 1.5$ & 84.4 & 0.5 & 30 & 60 & 3.08 \\
\hline
\end{tabular}

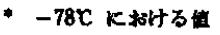

表 2 は室温において得られたボリマーの元素分析の結果であり， 宸素と水素の元素分析を行ない，酸素はこれらの值から計算して 求めた。

ポリマー組成に対するモノマー組成の影䇾ははとんどみられず, PP 量が CO 量上りも幾分多く，両者のモル比忙 1.3 1.4 であ 䒠。

表 2 共重合組成に対するモノマー組成の影整

\begin{tabular}{|c|c|c|c|c|c|}
\hline 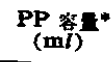 & $\underset{\left(\mathbf{k g} / \mathrm{cm}^{2}\right)}{\left.\operatorname{co}\right|^{*}}$ & 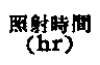 & $\begin{array}{l}\text { co*** } \\
(\%)\end{array}$ & $\begin{array}{l}\text { PP** } \\
(\%)\end{array}$ & $\underset{\text { (モル壮) }}{\text { PP/CO** }}$ \\
\hline 5.0 & 20 & 55.8 & 34.8 & 65.2 & 1.25 \\
\hline 5.5 & 32 & 159.1 & 33.6 & 66.4 & 1.32 \\
\hline 5.7 & 20 & 155.0 & 32.9 & 67.1 & 1. 36 \\
\hline 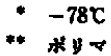 & 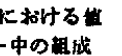 & & & & \\
\hline
\end{tabular}

表 3 は, $14 \pm 1.5^{\circ} \mathrm{C}$ の重合において得られたコポリマーのMEK (Methyl ethyl ketone) 中 $30^{\circ} \mathrm{C}$ での粘度测定の絬果である。

モノマー系のCO 王が高いほど，また重合時間が長いほど分子

性少の傾向にある。

Pinner $ら^{0)}$ は，イソブチレンの低温放射線重合炕括いて，2
表 3 共重合体の粘度

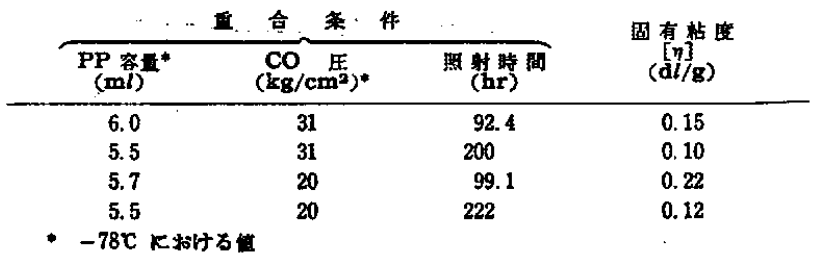

つの特徽がみられることを報告している。すなわち，照射線量と

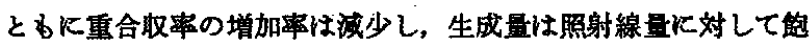
和する傾向にあり，他方，照射量ととすに重合度は娍少する。

これらの現象の説明として，次のようなことが考えられる。

1) 重合時間ととるに開始效率が減少する。

2）停止反応が照射線量ととるに速くなる。

3) 生成ポリマーが照射に上って分解していく。

PP-CO 采の重合炕いては，すで述へたように，モノマー

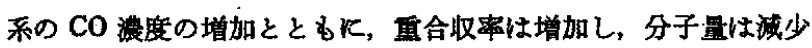
している。また，生成量は照射線量とともに值線的に增大してい る。従って,これらの現象をイソブチレンの場合の 1) 2）に 関連つけることは困難であり，次のように考えた方が妥当である。

1) PP よりるCO の方が重合を開始しやすい。

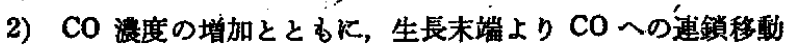
が起こり，励起された CO はたた゚ちに重合を開始する。

3）照射線量の增加にとるなって生しる分子量の低下は，おむ に生成ポリマーの分解に帰因する。

この共重合に拈いては，すでに述べたように，低温においては 重合取率の著しい减少が認められる。Brubaker ら゙はェチレン と一酸化炭素がラジカル共重合をすると報告している。

PP-CO 共重合の場合も，恐らく反応はラジカル機構であると 推定される。

図3和上び図4に得られたボリマーの赤外吸収スペクトルを示 す。このポリマーは典型的なケトン型のるのであり,プロピレン のホモポリマーとの重ね合わせとは異なったスペクトルを与え る。このうち，主なるのの㴆属について，表4のように推定した。 $1640 \mathrm{~cm}^{-1}$ 付近の弱い吸取は末端二重結合に基つくすのと思われ る。

コボリマーはグリース状の柔いポリマーであり，MEK，アセ卜 ン, エーテルおよび多量のベンゼンに可溶であり，メタノール，

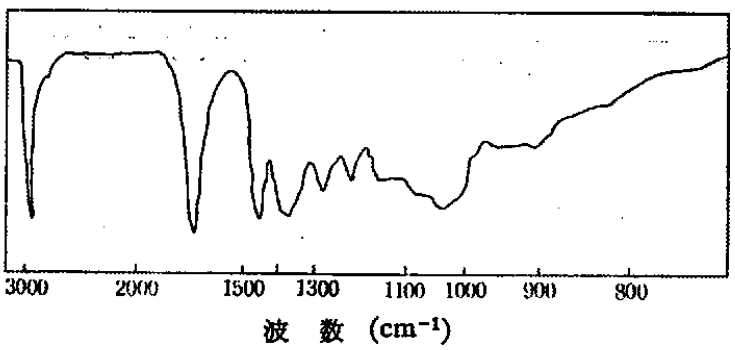

図 3 PP-CO コポリマーの赤外取取スベクトル $P_{\mathrm{co}}=20 \mathrm{~kg} / \mathrm{cm}^{2}(\mathrm{at}-78 \mathrm{C}), V_{\mathrm{Pp}}=5.7 \mathrm{ml}($ at $-78 \mathrm{C})$ 更合温度 : $14 \pm 1.5 \mathrm{C}$

6) Davison, Pinner, Worral, Chemistry and Industry (1957), 1274 ; Davison, Pinner, Worrall, Proc. Roy. Soc. A 252, 187 (1959) ; Worral, Pinner, J. Polymer Sci. 34, 229 (1959), 


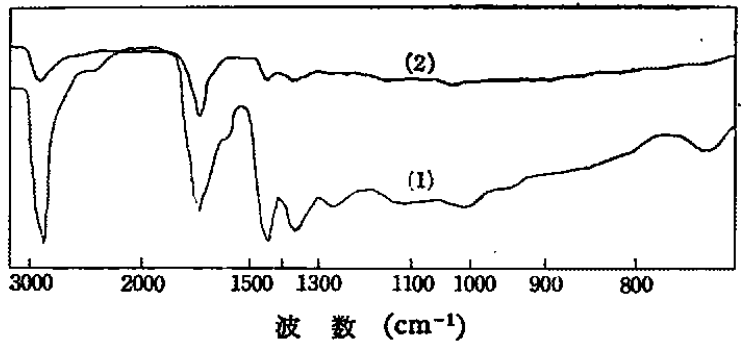

図 4 PP-CO コポทマーの赤外吸取スベクトル (1) $: 14 \pm 1.5 \mathrm{C}$ 合, $V_{\mathrm{pP}}=0.5 \mathrm{~m} l\left(\right.$ at $-78 \mathrm{C}$ ), $P_{\mathrm{CO}}=30 \mathrm{~kg} / \mathrm{cm}^{2}$ (at $-78 \mathrm{C}$ )

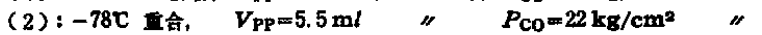

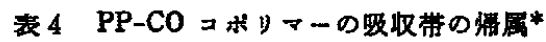

\begin{tabular}{|c|c|c|c|c|c|}
\hline $\begin{array}{l}\text { 波 } \\
\left.\left(\mathbf{c m}^{-1}\right)^{-1}\right)\end{array}$ & 强 度 & 兴 & $\begin{array}{l}\text { 波 } \\
\left(\mathrm{cm}^{-1}\right)\end{array}$ & 强英 & 嚅 需 \\
\hline 2960 & s & $\nu_{3}\left(\mathrm{CH}_{3}\right)$ & 1381 & s & $\boldsymbol{\delta}_{2}\left(\mathrm{CH}_{3}\right)$ \\
\hline 2925 & s & $\nu_{2}\left(\mathrm{CH}_{2}\right)$ & 1360 & $\mathbf{s}(\mathbf{s h})$ & $\mathrm{B}_{3}\left(\mathrm{CH}_{8}\right)$ \\
\hline 2880 & $\mathbf{g}(\mathbf{s h})$ & $v_{4}\left(\mathrm{CH}_{3}\right)$ & $1265\}$ & m & $\omega\left(\mathrm{CH}_{2}\right)$ \\
\hline 2820 & $w(8 h)$ & $\nu_{8}\left(\mathrm{CH}_{2}\right)$ & 1205 & $\mathbf{m}$ & \\
\hline 2740 & $\mathbf{w}$ & $1333+1382$ & 1142 & $\mathbf{m}$ & Skeletal \\
\hline 1705 & vs & $v(\mathbf{C}=\mathbf{0})$ & 1073 & $\mathbf{m}$ & \\
\hline 1640 & w & $v(\mathrm{C}=\mathrm{C})$ & 1040 & g & \\
\hline 1466 & 8 & $\left\{\left(\mathrm{CH}_{2}\right)\right.$ & 950 & $\mathbf{v w}$ & \\
\hline 1462 & & $\left(8_{2}\left(\mathrm{CH}_{3}\right)\right.$ & 910 & vw & \\
\hline 1442 & w (sh) & $\delta_{2}\left(\mathrm{CH}_{9}\right)$ & 810 & $\mathbf{v w}$ & Skeletal \\
\hline 1395 & B(sh) & $\delta(\mathbf{C}-\mathrm{H})$ & 750 & $\mathbf{v w}$ & $\gamma\left(\mathrm{CH}_{2}\right)$ \\
\hline
\end{tabular}

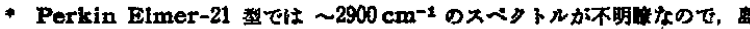
津 IR-27 C 型を使用

水には客けない。

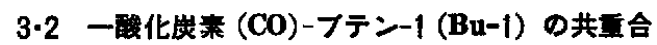

CO-Bu-1 系に和ける共重合の結果を表 5 に示す。重合收率は 非常に小さく，特に低温においては微量である。

得られたポリマーはグリース状の柔いポリマーであり，MEK

表 $5 \mathrm{CO}-\mathrm{Bu}-1$ の重合策件と取率

\begin{tabular}{|c|c|c|c|c|}
\hline 豆含望) & $\underset{(\mathrm{m} l)}{\mathrm{Bu}-1 \text { 容 }}$ & $\underset{\left(\mathrm{kg} / \mathrm{cm}^{2}\right)}{\text { 压 }}$ & $\begin{array}{l}\text { 照射時䦚 } \\
\text { (hr) }\end{array}$ & $\begin{array}{l}\text { 重含努事** } \\
\text { \% }\end{array}$ \\
\hline $14 \pm 1.5$ & 5.5 & 20 & 133.5 & 0.33 \\
\hline-78 & 5.0 & 30 & 90.6 & 0.06 \\
\hline
\end{tabular}

* -78C 火拮方值

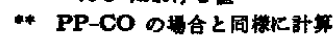

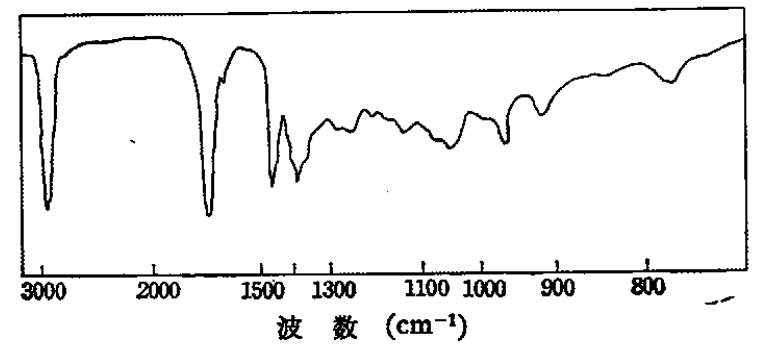

图 5 CO-Bu-1 コボทマーの赤外㖟取スベクトル

室漹重合

表 6 CO-Bu-1 コボッマーの吸収帯の㷌属

\begin{tabular}{|c|c|c|c|c|c|}
\hline $\begin{array}{l}\text { 波 } \\
\left(\mathrm{cm}^{-1}\right)\end{array}$ & 强 度 & 湮品 & 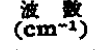 & 强度 & 增属 \\
\hline$\sim 2900$ & vo & $\begin{array}{l}v\left(\mathrm{CH}_{\mathrm{s}}\right) \\
v\left(\mathrm{CH}_{2}\right)\end{array}$ & 1250 & $\mathbf{w}$ & \\
\hline 1710 & vs & $v(\mathrm{C}=0)$ & 1200 & $v w$ & $\left.0 \times 1 x_{2}\right)$ \\
\hline 1640 & $\mathbf{w}$ & $x(\mathrm{C}=\mathrm{C})$ & 1165 & $\mathbf{v w}$ & Skeleta \\
\hline 1470 & 8 & $8\left(\mathrm{CH}_{2}\right)$ & 1135 & $\mathbf{w}$ & \\
\hline 1450 & $\mathbf{m}(\mathbf{s h})$ & $\mathrm{B}_{2}\left(\mathrm{CH}_{3}\right)$ & 1070 & w & \\
\hline 1400 & $\mathbf{m}$ (sh) & $\delta_{2}\left(\mathrm{CH}_{3}\right)$ & 1050 & $\mathbf{m}$ & \\
\hline 1390 & g & $\delta_{8}\left(\mathrm{CH}_{3}\right)$ & 1000 & $w$ & \\
\hline 1368 & $m$ (sh) & $\mathrm{B}_{\mathrm{a}}\left(\mathrm{CH}_{3}\right)$ & 970 & $\mathbf{m}$ & Skeleta \\
\hline 1345 & $w(s h)$ & $8(\mathrm{C}-\mathrm{H})$ & 915 & $\mathbf{w}$ & \\
\hline 1288 & w & $t\left(\mathrm{CH}_{2}\right)$ & 780 & $w$ & \\
\hline
\end{tabular}

に可溶である。

赤外吸取スペクトルおよびその㷌属について推定した結果を図 5, 表 6 に示す。

PP-CO コポリマーと同様，典型的なケトン型のポリマーであ り，末端二重結合に基つくと思われる吸収が $1640 \mathrm{~cm}^{-1}$ 付近に認 められる。

\section{3 一酸化炭来 (CO)-イソフチレン (IB) の共基合}

CO-IB 混合系における共重合の結果を表 7 K示す。この場合 6 CO-Bu-1 系と同様，全体として重合収率は低いが，見掛け上 低温の方が重合収率は高い。

\begin{tabular}{|c|c|c|c|c|}
\hline 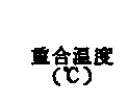 & $\begin{array}{l}\text { 表 } 7 \text { CC } \\
\text { IB 容清* } \\
\text { (ml) }\end{array}$ & $\begin{array}{l}\text { IB の重合 } \\
\mathrm{CO} \underset{\text { 和* }}{\left(\mathbf{k g} / \mathrm{cm}^{2}\right)}\end{array}$ & $\begin{array}{c}\text { 件 と収事 } \\
\text { 照射時䀡 } \\
\text { (hr) }\end{array}$ & $\begin{array}{c}\text { 直念收事** } \\
(\%)\end{array}$ \\
\hline $14 \pm 1.5$ & 4.9 & 30 & 92.1 & 0.18 \\
\hline-78 & 4.9 & 30 & 92.7 & 0.60 \\
\hline \multicolumn{5}{|c|}{ 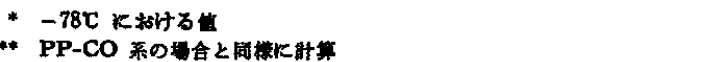 } \\
\hline
\end{tabular}

このポリマーも，グリース状の来いポリマーであり，室温にお いて得られたポリマーは MEK に溶けるが，低温におけるすのは はとんど溶けない。

室温および $-78^{\circ} \mathrm{C}$ にいて得られたか゚リマーの赤外夢収スペ クトルを図6に示す。

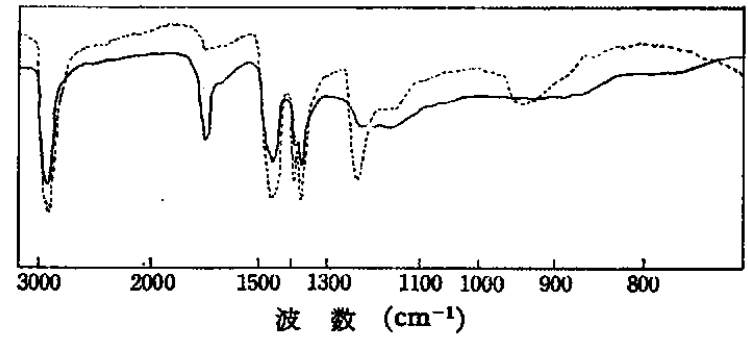

图 $6 \mathrm{CO}-\mathrm{IB}=$ ポリマーの赤外吸収スペクトル --- : 低浑重合 $(-78 \mathrm{C})$, 一：室温重合 $(14 \pm 1.5 \mathrm{C})$

PP-CO，Bu-1-CO 系と同様，ケトン型のボリマーであるが， -78C に括けるコポりマー中の CO 量はかなり少ないことが推 測される。

Pinner ら゚は，イソブチレンが低温でイオン重合をし，重合の 見卦けの活性化エネルギーが負であることを報告している。

以上の点を考慮すると，低温重合の场合はイソブチレンのホモ ポリマーも同時に生成して括り，従って見挂け上の重台収率は增 加したるのと思われる。

室温に枋いて得られたコポリマーの赤外吸収スペクトルの㷌属 は表 8 のよろに推定した。

表 8 CO-IB コボリマーの服収带の㷌属

\begin{tabular}{|c|c|c|c|c|c|}
\hline 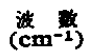 & 嬁 度 & 增屈 & $\begin{array}{l}\text { 波 } \\
\left(\mathbf{c m}^{-1}\right)\end{array}$ & 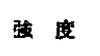 & 惯成 \\
\hline$\sim 2900$ & vs & $\begin{array}{l}\nu\left(\mathrm{CH}_{3}\right), \\
x\left(\mathrm{CH}_{2}\right)\end{array}$ & 1366 & vs & $\delta_{8}\left(\mathrm{CH}_{3}\right)$ \\
\hline 2740 & $\mathbf{w}$ & & 1345 & w (sh) & $8(\mathrm{C}-\mathrm{H})$ \\
\hline 1705 & $\mathbf{s}$ & $x(C=0)$ & 1225 & $\mathbf{w}$ & $\omega\left(\mathrm{CH}_{2}\right)$ \\
\hline 1640 & $w(g h)$ & $x(C=C)$ & 1145 & $\mathrm{w}$ & skeletal \\
\hline 1480 & $\mathrm{~m}(\mathrm{sh})$ & $8\left(\mathrm{CH}_{2}\right)$ & 945 & & \\
\hline 1462 & & $\mathrm{~S}_{\mathrm{a}}\left(\mathrm{CH}_{3}\right)$ & 920 & & \\
\hline 1448 & $\mathbf{m}(\boldsymbol{s} \mathbf{h})$ & $\delta_{a}\left(\mathrm{CH}_{3}\right)$ & 885 & & \\
\hline 1390 & 8 & $8_{8}\left(\mathrm{CH}_{\mathrm{g}}\right)$ & & & \\
\hline
\end{tabular}

プピレンの提供を载いた新日本空和肥料株式会社に榙意を表 す。な拉，この研究結果は昭和 39 年 4 月, 日本化学会第 17 年 会（東京）において発表した。 